DOI: $10.17516 / 1997-1370-0838$

УДК 811.161 .1

\title{
On the History of the Vocabulary of the Thematic Group «Christian Virtues and Sins»: Based on the Translated Church Slavonic Hymnography
}

\author{
Tatiana S. Borisova* \\ School of Philosophy \\ National and Kapodistrian University of Athens \\ Panepistimiopolis, Athens, Greece
}

Received 30.08.2021, received in revised form 02.09.2021, accepted 14.09.2021

\begin{abstract}
This study examines the formation and further evolution of the Church Slavonic and Russian vocabulary describing Christian virtues and sins. Our research was conducted on the available Church Slavonic translations of four Byzantine hymns (the Akathistos Hymn, the Great Canon of Repentance by St. Andrew of Crete, the Alphabetical Stichera from the Great Canon service, and the Great and Holy Friday Antiphons) found in Southern and Eastern Slavonic manuscripts of the $11^{\text {th }}-16^{\text {th }}$ century, as well as Russian editions dating back to the $17^{\text {th }}$ - early $20^{\text {th }}$ century. The textological study revealed five main stages in the evolution of these texts caused by systematic corrections in accordance with the Greek text. Based on these results, the linguistic textological method was applied in order to reveal the main differences between said stages in regard to conveying terms relevant to Christian virtues and sins. We examined a total of 110 Greek words and idiomatic expressions in this thematic field and classified them following the method suggested by E. M. Vereshchagin who focused on ways of terms creation. There were revealed main ways these terms were formed in the target language and the general tendencies in their translation during different stages in the history of Church Slavonic. The results of our research showcased the leading role of transposition in the formation of the terms, the negligible amount of lexical loans, as well as the growing role of calquing in the history of Church Slavonic. We also showed the ways in which the Church Slavonic and Russian languages adopted new linguistic and cultural realities and reinterpreted the system of Greek ethical terms, which helps us understand the mechanisms of intercultural transfer, as well as the linguistic factors that contribute to the identification of Russian culture in the general Orthodox context.
\end{abstract}

Keywords: linguistic textological method, historical lexicology, hymnography, Church Slavonic translations, Christian terminology, Greek-Slavonic linguistic relations.

Research area: linguisctics.

(C) Siberian Federal University. All rights reserved

* Corresponding author E-mail address: tatianaborissova@gmail.com 
Tatiana S. Borisova. On the History of the Vocabulary of the Thematic Group "Christian Virtues and Sins"...

Citation: Borisova, T.S. (2021). On the history of the vocabulary of the thematic group «Christian Virtues and Sins»: based on the translated Church Slavonic Hymnography. J. Sib. Fed. Univ. Humanit. soc. sci., 14(10), 1547-1555. DOI: 10.17516/1997-1370-0838

\title{
К истории лексики тематических полей «христианские добродетели и пороки» в русском языке: на материале церковнославянской гимнографии
}

\section{Т.С. Борисова}

Институт философии

Афинский национальный университет им. И. Каподистрии

Греция, Афиньл

\begin{abstract}
Аннотация. В работе рассмотрено формирование и дальнейшее развитие церковнославянской и русской лексики, обозначающей христианские добродетели и пороки. Исследование проводилось на материале церковнославянских переводов четырех византийских гимнографических произведений (Акафиста Богоматери, Великого покаянного канона Андрея Критского, Алфавитных стихир из последования Великого канона и Антифонов Великой Пятницы), рассмотренных по южнославянским и восточнославянским рукописям XI-XVI веков и русским изданиям XVII - начала $\mathrm{XX}$ века. Предварительное текстологическое исследование выявило 5 основных стадий истории данных текстов, в основе которой лежали систематические справы славянского текста в соответствии с греческим оригиналом. Опираясь на данные результаты, мы применили лингвотекстологический метод с целью выявить основные различия между данными стадиями в передаче терминов, обозначающих христианские добродетели и пороки. Всего в рассмотренных текстах было обнаружено 110 лексем и устойчивых выражений данного тематического поля, проанализированных на основе классификации способов формирования терминологии, предложенной Е. М. Верещагиным. Были выявлены как основные пути создания терминов, так и тенденции в способах их перевода на разных стадиях истории церковнославянского языка. Результаты исследования показали ведущую роль транспозиции при создании терминологии, ничтожно малый процент лексических заимствований, а также возрастающую роль калькирования по мере развития языка. Кроме того, были рассмотрены процессы языковой адаптации и переосмысления греческой терминологии в системе принимающего языка, помогающие понять механизмы межкультурного взаимодействия, а также лингвистические факторы, способствующие поиску идентичности русской культуры в широком православном контексте.
\end{abstract}

Ключевые слова: лингвотекстологический метод, историческая лексикология, гимнография, церковнославянские переводы, христианская терминология, греческославянские языковые связи.

Научная специальность: 10.02.00 - языкознание. 


\section{Introduction}

This study focuses on the phenomenon of interlingual communication based on the case study of the influence the Greek language had over the Russian language. This influence, although well-known, has mostly been mentioned by great Russian authors instead of linguists. At this point, it is useful to cite the words of two such authors, namely A. Pushkin, who wrote the following: «As material for verbal art, the Slavonic-Russian language has an indisputable advantage over all European languages: it has had an unusually fortunate course. In the $9^{\text {th }}$ century, the Ancient Greek language suddenly opened its lexicon, the treasure of its harmony, donated the rules of its well-considered grammar, its beautiful constructions, its imposing stream of speech, in other words, it adopted it [the Russian language], freeing it in this way from slow time-consuming improvements. Sonorous and expressive on its own, it [the Russian language] henceforth borrows flexibility and correctness» (Pushkin, 1964: 27); as well as a fragment from the letter of V. Zhukovsky to I. Turgenev: «... I regard the Greek language with admiration, and I consider it necessary for the improvement of Russian, because our Russian language was brought up by Greek, from which our first books were translated...» (Zhukovsky, 1895: 70).

One can easily see that such an important influence as described by these great classic authors cannot simply be limited to loan words; there are much deeper and systematic processes at play. The Greek language was introduced to Slavs alongside Christianity and the Byzantine culture. A new system of ethical values was introduced to the Slavic world to be subsequently creatively adopted by Slavs and interpreted in the context of the Slavic culture and language. It was this mix that laid the foundations of the Russian language and culture described by the aforementioned classic authors. This cultural transfer was naturally bound to a concurrent linguistic transfer, with the new concepts that appeared in the cultural framework being followed by new words that described them in the linguistic framework. This article examines the process through which these words were formed, as well as the role of the Greek language in said process, based on thematic groups of words that denote Christian virtues and sins.

To a regular believer, Christianity first and foremost means a new ethical code. The adoption of this code should happen both on a cultural and linguistic level, the latter accompanied by the formation of new thematic vocabulary groups with corresponding positive or negative connotations. These could have changed during the transition from paganism to Christianity due to the new ethical evaluation of some character traits in the Christian ethical system.

The new vocabulary in the Church Slavonic and Russian languages was formed during the translation process, as well as through subsequent reviews of the most important texts of the Byzantine Christian culture and their later adaptation to the environment of the target language. It was formed by translators and reviewers who tried to find the best Slavonic counterparts with the maximum possible semantic equivalence, in order to describe the complex abstract concepts in the Greek language. The purpose of this was not only to translate and compose the sacred texts but to also render them comprehensible to the Slavonic audience. Among these texts, hymnography was of special importance, as it significantly facilitated the textual conveyance to the medieval man, regulated the usage of the language in the sphere of religious literacy, and formulated the ethical code of the believers. The role of Greek hymnography in Russian ethics, especially that of the Great Canon of Repentance by St. Andrew of Crete, was highlighted by F. Dostoyevsky, who wrote: «Humanity... Russian people don't need it from Europe. They know to forgive. It is enough for them to read the Great Canon by St. Andrew of Crete» (Dostoyevsky, 1971: 463). However, the available hymnographic material has not been sufficiently studied from the point of view of historical lexicology.

\section{Statement of the problem}

This research constitutes an attempt to analyze the formation of the vocabulary of the Church Slavonic language from a histor- 
ical perspective, based on the Slavonic translations of four Byzantine texts of the Triodion cycle: the Akathistos Hymn; the Great Canon of Repentance by St. Andrew of Crete; the Alphabetical Stichera from the Great Canon service; and the Antiphons of the Great and Holy Friday, in both their manuscript and published versions dating from the $9^{\text {th }}$ to the early $20^{\text {th }}$ century. More specifically, we will examine how the lexemes denoting Christian virtues and sins in these Greek hymnographic texts were translated in Church Slavonic in the first translations $\left(9^{\text {th }}-\right.$ early $10^{\text {th }}$ century), as well as whether these translations have changed during the process of textual revision (Bobrik, 1990). The goal is to reveal the main ways the system of Russian terms describing the ethical categories of virtues and sins was formed, as well as the general tendencies in the formation of these words during different stages in Church Slavonic history.

\section{Materials and methods}

This research was conducted on Greek academic and church editions (Migne, 1860; Triodion, 1867; Trypanis, 1968), Church Slavonic manuscripts of the $11^{\text {th }}-16^{\text {th }}$ century (Triodia; Pentecostaria; Kondakaria; and Sticheraria), which contain the abovementioned texts (Borisova, 2020: 537-544), as well as Slavonic editions of the $17^{\text {th }}-20^{\text {th }}$ century (Postnaia Triod', 1663; Triod' Postnaia, 1912). The analysis of the material in the Church Slavonic language was based on the textological study of the abovementioned translated hymns (Borisova, 2020a) that we carried out in the past and which has helped distinguish the main versions (reductions) of said translations in the Church Slavonic tradition, as well as the main stages in its history. More specifically, the following stages were examined:

1. The early South Slavonic versions (late $9^{\text {th }}-$ early $10^{\text {th }}$ century), which reflect the first Slavonic translations made by the disciples of St. Cyril and Methodius (Borisova, 2020a: 50$62 ; 66-76)$. Two relatively independent translations connected to the Glagolitic and Cyrillic traditions were most likely completed in the South Slavic region at this stage. These versions have not been saved in their entirety and can be reconstructed based on fragments from the South Slavonic manuscripts of the $12^{\text {th }}-$ $13^{\text {th }}$ century, hereinafter referred to as Stage 1.

2. The stage which began with the Preslav corrections in the mid-late $10^{\text {th }}$ century (Borisova, 2020a: 62-66), a relatively large volume of text material was preserved in the East Slavonic manuscripts of the $11^{\text {th }}-14^{\text {th }}$ century, as well as the Bulgarian manuscripts of the $13^{\text {th }}$ century, hereinafter referred to as Stage 2.

3 . The stage which began with a systematic correction of the liturgical books carried out on Mount Athos near the end of the $13^{\text {th }}$ century (Borisova, 2020a: 94-102). The material was preserved in numerous South Slavonic manuscripts of the $14^{\text {th }}-16^{\text {th }}$ century, as well as in East Slavonic manuscripts of the $15^{\text {th }}-16^{\text {th }}$ century. This stage is hereinafter referred to as Stage 3.

4. The stage which refers to the correction of the liturgical books in Kiev in the first half of the $17^{\text {th }}$ century followed by the new versions of the liturgical books that appeared as a result of the book revision carried out by Patriarch Nikon in the second half of the $17^{\text {th }}$ century (Borisova, 2020b; Bobrik, 1990: 73-78), hereinafter referred to as Stage 4.

5 . The stage which is connected to the editions of the Holy Synod (Sinodalnaja) in the beginning of the $20^{\text {th }}$ century and corresponds to the contemporary Russian Orthodox liturgical practice, hereinafter referred to as Stage 5.

Detailed information regarding the versions of the texts corresponding to each stage, as well as the illustrative manuscripts through which the linguistic material from each stage was collected is provided in our earlier works (Borisova 2020a; Borisova 2020b).

The linguistic material was collected according to the linguistic textological method (Panin, 1995), while the subsequent analysis of the Greek and Church Slavonic material was carried out following the comparative etymological and semantic methods and the methods of cultural linguistics. The etymological and semantic analysis of the Greek and Slavonic lexemes was conducted on Greek and Russian lexicographic sources (Lampe, 1961; Stamatakos, 1972; Slovar' russkogo iazyka 11-17 vekov; Vasmer, 1987; Krylov, 2005). 


\section{Theoretical framework}

The linguistic data analysis was based on the classification of the ways the aforementioned terms formed in the Old Slavonic (Church Slavonic) language, as suggested by E.M. Vereshchagin (Vereshchagin, 1988). More precisely, there are four main ways new vocabulary was formed with the purpose of translating terms in Greek texts unknown to Slavs:

1. Transposition - addition of new terminological meaning corresponding to the source language (Greek) to the lexeme that already existed in the target language (Church Slavonic);

2. Lexical loan - transfer of the lexeme from the source language to the target language;

3. Calquing - creation of a term in the target language based on the transfer of the morphological structure of the source language;

4. Mentalization - creation of a term in the target language based on the transfer of the semantics of the source language.

It should be stressed that lexemes that have already existed in the target language are used only in the case of the first method; in the other three methods, these are new words that appear in the target language.

\section{Results and Discussion}

When discussing the contexts examined below, the following indication system will be used, with the relevant numbers within brackets:

- Akathistos Hymn - hereinafter referred to as Ak (oikos number in the Greek tradition from 1 to 24);

- Great Canon of Repentance by St. Andrew of Crete - hereinafter referred to as GC (ode number: number of heirmos (only for odes 2 and 3 with two heirmoi): troparion number (excluding heirmos));

- Alphabetical Stichera from the Great Canon service - hereinafter referred to as AS (sticheron number);

- Antiphons of the Great and Holy Friday - hereinafter referred to as An (antiphone number: troparion number).

In the texts under research, we discovered a total of 110 Greek nouns and idiomatic expressions associated with the thematic field
«Christian virtues and sins» in 224 different contexts. For comparative purposes, we also studied 24 adjectives and adverbs, as well as 12 verbs that cognate with the nouns under analysis. The number of Church Slavonic equivalents during Stage 1 and Stage 2 was much smaller (78), since scholars used the same have word to translate several Greek terms with a similar meaning. At early Stage 3 that number of Church Slavonic counterparts is practically the same as the corresponding Greek vocabulary due to the fact that the Athonite reviewers found a Slavonic equivalent for each Greek term. The translation work of the Athonite School scholars enriched the Church Slavonic vocabulary by approximately $20 \%$ in this thematic field and, in combination with several additions from Nikon's and the Synod's corrections, they formed the system the Russian language has been using to this day.

One can observe the main tendencies in vocabulary formation through the example of some terms with the general meaning of sin. The term гproxz, which appeared during Stage 1 in the first Church Slavonic translations to transpose the Greek word $\dot{\alpha} \mu \alpha \rho \tau i \alpha$ (the Greek and Slavonic words had a similar history in their corresponding languages: from the common meaning of failure, fault, or error, to the Christian terminological meaning of sin), had also been used until the $13^{\text {th }}$ century for the Greek nouns है $\gamma \kappa \lambda \eta \mu \alpha, \pi \alpha \rho \alpha \dot{\pi} \tau \omega \mu \alpha$, and $\pi \tau \alpha i \sigma \mu \alpha$. It was only during Stage 3 when the derivatives съгрғшеніе, прггргишеніе, and гргххопаденіе appeared in the translation of the texts to provide Slavic equivalents to each of

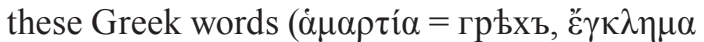
$=$ сьгрђшеніе, $\pi \tau \alpha i ́ \sigma \mu \alpha=$ прьгрђшеніе, $\pi \alpha \rho \alpha ́ \pi \tau \omega \mu \alpha=$ грьхопаденіе). However, contrary to the Greek language, all the abovementioned Slavic terms are cognates with not only semantic but also etymological relations, which make the Slavic system different from the Greek system.

As far as the abovementioned methods of vocabulary formation are concerned, the lexical material studied is divided as follows:

1. Transposition was the most popular method of terminology composition in the beginning of the history of Church Slavonic 
(Stage 1: 72 Greek lexemes and idiomatic expressions), and has kept this significant role in the thematic group under analysis to this day (Stage 5: 60 Greek lexemes and idiomatic expressions). Some highlights are as follows:

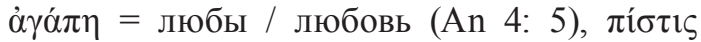
$=$ въра (Ak 7; GC5:18; 9:17; AS11), غ̇ $\lambda \pi \mathrm{i} \varsigma=$

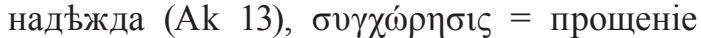
(Ak 13), $\mu \varepsilon \tau \alpha ́ v o 1 \alpha=$ пока^ніе (GC1:2; 2:1:25 and so on; AS6; 12), фóßо = страхъ (AS7),

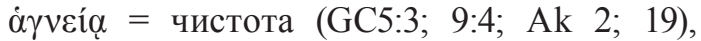

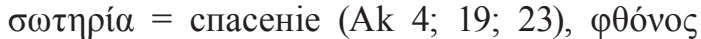
= зависть (AS21), о’ $\gamma \gamma \tilde{\eta}$ = гнъвъ (GC2:2:4; 7:7), какі́ $\alpha$ зьлоба (Gc 4:4: 5:4; 8:6), фо́vо

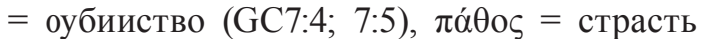

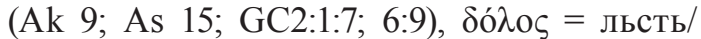
лесть (An 3:4; 4:2), $\dot{\alpha} \sigma \omega \tau i ́ \alpha=$ блждъ / блуд

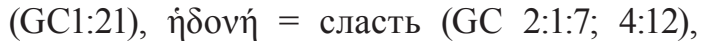
$\psi \varepsilon v \tilde{\delta o \varsigma}=$ лъжа / ложь (Ak 11).

It should be noted that sometimes the Slavonic counterpart suggested by the first translators remained throughout the history of Church Slavonic despite the differences in etymological meaning. A typical example is the term $\mu \varepsilon \tau \dot{\alpha} v o l \alpha$ which represents an important concept in Christian ethics and, according to its etymology, means the transformation of the mind $(\mu \varepsilon \tau \dot{\alpha}+v o t \alpha)$. The Slavic word поканніе/ покаяние has quite a different etymology; it originates from the verb каять which means swear with the reflexive suffix $-c я$. However, it was this specific word that was used in all Church Slavonic versions from the very first one to this day.

2. Contrary to the previous method, linguistic loans were practically nonexistent throughout the subsequent stages of Church Slavonic history. Only one such case was found in the words under analysis. Moreover, the certain loan word was not from the source language of the cultural transfer (Greek), but from the Old High German language. The lexeme nocms $=$ fast (from the Old High German fasto), used to

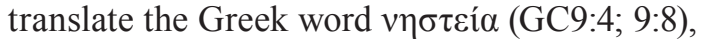
appeared at Stage 2 during the Preslav corrections. Earlier, that same Greek word was translated via transposition: альканіе = hunger . The rejection of loans as a method of language expansion could be explained as an attempt to provide the Slavs with ethical terminology that was easy for them to perceive and comprehend, thanks to its clear etymology.

3. Calquing was used for Greek derivatives as well as composites. At the early stages, it was not a very common practice, with the total lexemes in the thematic group under analysis being only 18 at Stage 1 . The most typical examples are: $\dot{\varepsilon} \gamma \kappa \rho \alpha ́ \tau \varepsilon 1 \alpha=$ въздрьжаніе (Ak 13); $\varphi \imath \lambda \alpha \delta \varepsilon \lambda \varphi{ }^{\prime} \alpha=$ братолюбіе (An 4:5); $\pi \alpha \rho \theta \varepsilon v i ́ \alpha$ $=$ дъвьство (Ak 19); $\theta \varepsilon о \sigma \varepsilon ́ \beta \varepsilon เ \alpha=$ богочьстіе

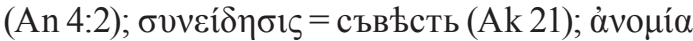
= безаконіе (GC2:2:9); $\dot{\alpha} \delta \eta \varphi \alpha \gamma i ́ \alpha=$ объАденіе (GC6:6). Starting from Stage 3 and leading up to Stage 5, the number and the percentage of these words gradually increased, reaching 38 . More information regarding this process along with more examples will be provided below.

4. Mentalization as a word formation process in the target language is especially interesting. Similar to calquing, the new words or idiomatic expressions are formed using components that arise from the target language copying the structures of the source language. Contrary to calquing, however, what is copied is semantics and not a morpheme structure. One can observe this process through the example of the general term $\dot{\alpha} \rho \varepsilon \tau \eta \dot{~ a n d ~ t h e ~ c o r r e s p o n d-~}$ ing Slavonic word добродгтель. Etymological dictionaries (Krylov, 2005: 115) state that the Slavonic term appeared as a calque of the

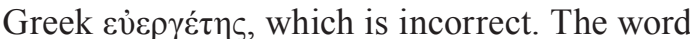

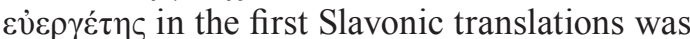
translated using another calque - благодътель

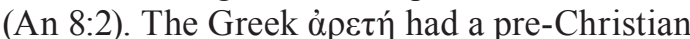
history. Before becoming a Christian ethical term, it had the general meaning of goodness, excellence, kindness. Therefore, unsurprisingly, at Stage 1, the transposition добро was used to translate it. However, later reviewers found the meaning of the word not specific enough to describe this Christian virtue and, at Stage 2 (Preslav correction), the Slavonic term добродгттель was suggested (GC8:2; 8:13). The new word was influenced by the Greek language, though it did not copy the structure of the non-derivative Greek word, but rather its semantics with the use of Slavonic roots.

Other examples of this mentalization process were the words благодтьть (Stage 1)/ благодать $=$ grace $($ Stages 2-5) for the Greek 


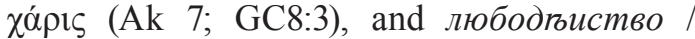
пргллюбодгиство = adultery for the Greek

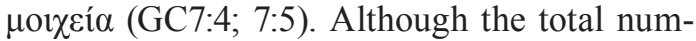
ber of words and idiomatic expressions with mentalization is relatively small and gradually decreasing (20 at Stage 1 and 9 at Stage 5), the words formed this way played an important role in the linguistic culture of Orthodox Slavs.

Let us now denote and discuss two main tendencies in the formation of the words under analysis during the history of Church Slavonic: from transposition to calquing and from mentalization to calquing. The first is depicted in the translation of the Greek $\alpha v \delta \rho \varepsilon i ́ \alpha$ (GC4:13) first as доблесть = courage (transposition) and, later, starting from Stage 3, as мжжьство/ мужество $=$ manhood (calque). Another similar example are the Slavonic equivalents to

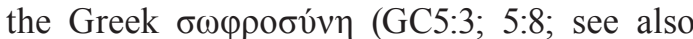
the translation of the cognate verb in GC9:16 and adjective in Ac 6) from the transposition мждрость $=$ wisdom at Stage 1 , to the calque цБломждріе/ целомудрие = chastity in subsequent stages.

The transition from mentalization to calquing is illustrated by the history of the Slavonic term добродътель as described above, as well as by the formation of the word отчаннiе instead of нечалніе in the first translations of the Greek derivative $\dot{\alpha} \pi$ ó $\nu \omega \sigma 1 \varsigma$ (GC6:13; 9:17), златолюбіе instead of сребролюбіе for the Greek composite $\varphi 1 \lambda \alpha \rho \gamma v \rho i ́ \alpha$ (GC8:6, An 2:2; $4: 1 ; 4: 2)$, благочестіе instead of благовтріе

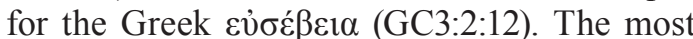
striking example, however, is the history of the Slavonic counterparts to the Greek term $\varepsilon v ่ \sigma \pi \lambda \alpha \gamma \chi v i$ í (GC2:1:5; 8:10; AS4), which were gradually formed by copying not only the semantics but also the morpheme structure of the Greek noun. In Stages 1-3, it was translated as милосрьдie (mentalization) with the use of the composite morpheme structure of the corresponding Latin term misericordia. Later, the term благосрьдіе (calque of the first Greek root and mentalization of the second one) appeared in the Russian tradition, which at Stages 4-5 resulted in the full calque благоутробіе. Nevertheless, this calque was not adopted in the Russian language, which contrary to Church Slavonic, keeps using the word милосердие to mean mercy, connecting this Christian virtue with the heart instead of the womb.

More examples that illustrate the intensive search of Slavic scholars for the best Slavonic equivalents to the complex concepts of the Greek language and culture are presented below:

- $\theta \eta \lambda v \mu \alpha v i ́ \alpha \quad(\mathrm{GC} 4: 12) \rightarrow$ блждъ (Stage 1) $\rightarrow$ тиннолюбие (Stage 2) $\rightarrow$ женонеистовьство (Stage 3-5);

- $\quad \dot{j} \delta v \pi \alpha \theta \varepsilon i ́ \alpha(\mathrm{GC7}: 11) \rightarrow$ наслаждение страстеи (Stage 1) $\rightarrow$ сласть (Stage 2) $\rightarrow$ сладострасть (Stage 3-5);

- $\quad \dot{\alpha} v \varepsilon \xi i ́ \kappa \alpha \kappa о \varsigma(A S 10,24) \rightarrow$ не памАть зълымь (Stage 1) $\rightarrow$ незлобивъ (Stage 2) $\rightarrow$ безлобывъ (Stage 3) $\rightarrow$ незлобивыи (Stage 4-5);

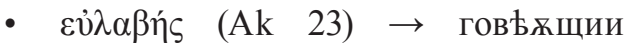
(Stage 1) $\rightarrow$ благобоязьныи (Stage 2) $\rightarrow$ благоговьиныи (Stage 3-5).

In the lexical material discussed above, one can easily observe how the Church Slavonic and Russian languages provide new connotations, language relations, and etymological semantics to the Christian terms borrowed from Greek culture. In order to further explain this process, we should examine another example, the multifunctional and polysemic Russian root-люб-. As it has already been shown, that same root was used to translate the core Christian virtue $\alpha \gamma \alpha \dot{\alpha} \pi \eta$ (любовь) alongside a number of sins, both via calquing the Greek root $\varphi 1 \lambda$ (е. g. фı $\lambda \alpha \rho \gamma v \rho i ́ \alpha /$ златолюбіе) and via men-

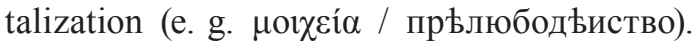
The use of this root in words with a negative connotation, which is impossible for the Greek concept of $\dot{\alpha} \gamma \alpha \dot{\alpha} \pi \eta$, forms the language basis of the ambivalent attitude towards the concept of love in Russian culture, which is perceived as a virtue and a sin simultaneously. Concepts that are at opposite poles in the Greek ethical code are now etymologically and semantically connected, with this linguistic association of vice and virtue forming a unique modus in Russian culture, where the most ignoble feelings also contain a reflection of Divine light.

\section{Conclusion}

To summarize the results of our research, it is important to state the effectiveness of the 
linguistic textological method in the study of comparative lexicology and cultural linguistics. Analyzing the evolution of the language in these particular translated texts with a wide historical perspective provides the researcher with objective statistic data and a more precise picture of the Greek-Slavonic interlingual communication.

The four Greek hymnographic texts studied through their Slavonic translations dating from the $9^{\text {th }}$ until the early $20^{\text {th }}$ century provided us with 110 words and idiomatic expressions in the thematic field "Christian virtues and sins»y. Among the methods for translation of these terms into Church Slavonic, lexical loans were almost not used at all, while the most frequent method observed was transposition, i. e. the use of words that pre-existed in the target language and Slavic pagan culture to create new Christian terminology meanings. In this way, the Christian religion became connected to the pagan substrate of the target culture.

The new words for the new concepts of Christian ethics were formed in two ways: calquing, i. e. copying the morphological structure of the source language lexeme; and mentalization, i. e. copying its semantic structure. The main tendency observed in the material under analysis was a transition from semantic description to morpheme correlation (calquing). We also observed a gradual increase in the number of Slavonic lexemes in this particular thematic field, due to Slavic scholars at- tempting to find Slavonic counterparts to every Greek word, as well as different Slavonic equivalents to similar but not exactly the same Greek notions. It was this aspiration for an exact reproduction of the Greek texts at all levels - grammatical, conceptual, symbolic, that defined the essence of the work of generations of Slavic scholars, along with the development of Church Slavonic as the language capable of the most adequate transfer of the Greek Orthodox culture into the Slavic world. This was the «search for Byzantium» which defined the core tendency of Russian spirituality for many centuries. Grammar and vocabulary morphed into theology and ethics, and text revisions became milestones in the history of Russian culture. On the other hand, a transfer to the system of another language can form other correlations between words and key concepts of culture, balancing between the common Orthodox Byzantine elements and the original Slavic elements and searching for an identity and unique place in global culture. Comparing the linguistic data of the Greek, Church Slavonic, and Russian languages at different times, one can better understand both the linguistic features of the latter and the basic concepts of Orthodox Slavic culture. These were formed on the basis of the interlingual interpretation of the Byzantine heritage, as well as an original linguistic and cultural components that determined the special place of Russian culture among other Orthodox cultures.

\section{References}

Bobrik, M.A. (1990). Predstavleniia o pravil'nosti teksta i iazyka v istorii knizhnoi stravy v Rossii (ot 11 do 18 veka) [Ideas about the correctness of the text and language in the history of the book correction in Russia (from the $11^{\text {th }}$ to the $18^{\text {th }}$ century)], In Voprosy Iazykoznaniia [Topics in the Study of Language], 4, 61-81.

Borisova, T.S. (2020a). Istoriia russkogo literaturnogo iazyka po dannym lingvotekstologicheskogo analiza perevodnykh pamiatnikov (na materiale gimnograficheskikh tekstov triodnogo tsikla). Dissertatsiia na soiskanie uchenoi stepeni doktora fililogicheskikh nauk [History of Russian literary language based on the data of linguistic textological analysis of translated text (on the material of hymnographic texts of Triodium cycle. Thesis for the degree of Doctor of Philological Sciences]. Novosibirsk, 2020, 544 p.

Borisova, T.S. (2020b). Knizhnaia sprava 17 vera v istorii tserkovnoslavianskogo perevoda Akafista Bogomateri $\left[17^{\text {th }}\right.$ century book correction in the history of the Church Slavonic translation of the Akathist Hymn], In Sibirskii Fililogicheskii zhurnal [Siberian Journal of Filology], 2, 266-276.

Dostoevsky, F.M. (1971). Neizdannyi Dostoevsky. Zapisnye knizhki i tetradi 1860-1881 [Unpublished Dostoevsky. Diaries and notebooks 1860-1881]. Moscow: Nauka, 727 p. 
Zhukovskii, V.A. (1895). Pis'ma V.A. Zhukovskogo k A.I. Turgenevu [Letters of V.A. Zhukovsky to A.I. Turgenev]. Moscow: Russian Archive Publ. 322 p.

Krylov G. A. (2005). Etimologicheskii slovar' russkogo iazyka [Etymological dictionary of the Russian Language], Saint-Petersburg: Poligrafuslugi, 432 p.

Lampe, G.W. (1961). A Patristic Greek Lexicon. New York, Oxford University Press, 1568 p. Migne, G. (1860). Patrologiae Cursus Graecae [Greek Patrology], 97. Paris, 1654 p.

Panin, L.G. (1995). Istoriia tserkovnoslavianskogo iazyka i lingvisticheskaia tekstologiia [History of Church Slavonic language and linguistic textology]. Novosibirsk, Novosibirsk State University Publishing House, $218 \mathrm{p}$.

Postnaia Triod' [Lenten Triodion] (1663). Moscow: Pechatnyi Dvor.

Pushkin, A.S. (1964). Polnoe sobranie sochinenii v 10 tomakh [Complete works: in 10 volumes], 7. Moscow, AS USSR Publ.

Slovar' russkogo iazyka 11-17 vekov [Dictionary of Russian Language of $11^{\text {th }}-17^{\text {th }}$ century], (19742008),1-28. Moscow.

Stamatakos, I. (1972). Lexikon Arxaias Ellinikis Glossis [Dictionary of the Ancient Greek language]. Athens, Foinix, $1261 \mathrm{p}$.

Triodion Kataniktikon [Lenten Triodion] (1867). Venice, 455 p.

Triod' Postnaia [Lenten Triodion] (1912). Moscow: Synod Publ., 1135 p.

Trypanis, C. (1968). Fourteen Early Byzantine Cantica. Vienna, 171 p.

Vasmer (Fasmer), M. (1987). Etimologicheskii slovar' russkogo iazyka [Etymological dictionary of the Russian Language], 1-4, Moscow: Progress.

Vereschagin, E.M. (1988). Dve linii v iazykotvorchestve Kirilla i Mefodiia i ikh posledovatelei: formirovanie terminologii, sozdanie poeticheskoi traditsii [Two lines in the linguistic work of Cyril and Methodius and their followers: the formation of terminology, the creation of a poetic tradition], In Slavianskoe iazykoznanie. 10 Mezhdunarodnyi sezd slavistov. Doklady sovetskoi delegatsii [Slavic linguistics. $10^{\text {th }}$ International Congress of Slavists. Reports of the Soviet Delegation]. Moscow: Nauka, 78-90. 